\title{
Article/Artigo
}

\section{Occurrence of synanthropic triatomines (Hemiptera: Reduviidae) in the Federal District of Brazil}

\author{
Ocorrência de triatomíneos sinantrópicos (Hemiptera: Reduviidae) no Distrito Federal, Brasil
}

Maicon Hitoshi Maeda ${ }^{1,2}$, Monique Britto Knox ${ }^{3}$ and Rodrigo Gurgel-Gonçalves ${ }^{2}$

\begin{abstract}
Introduction: Entomological surveillance of Chagas disease in the Federal District of Brazil (DF), has recorded the following triatomine species: Panstrongylus megistus, P. geniculatus, P. diasi, Rhodnius neglectus, Triatoma pseudomaculata, and T. sordida. We aimed to analyze the spatial and temporal occurrence of triatomine species collected in DF, and their indices of natural infection with trypanosomes. Methods: The Health State Secretariat of DF recorded triatomines between 2002 and 2010 in 20 administrative regions. This retrospective analysis considered the number of adults and nymphs of each species collected and infected in both intradomicile and peridomicile. Results: A total of 754 triatomines were collected in 252 reported domiciles. Panstrongylus megistus was the most frequent species $(65 \%)$, followed by T. pseudomaculata (14\%). Of the 309 examined insects, only 3 (1\%) specimens of P. megistus were infected with flagellates morphologically similar to Trypanosoma cruzi. The spatial occurrence indicated a higher diversity of triatomines and frequency of T. sordida in rural areas. Moreover, there was a predominance of $P$. megistus in urban areas. The number of records of $P$. megistus in the rainy season was two times higher than that during the dry season. The largest number of triatomines was collected in November. Conclusions: The presence of $P$. megistus specimens infected with trypanosomes in domiciles, shows the potential risk of human infection in DF. Thus, it is essential to continue entomological surveillance, intensifying it in the rainy season and in regions of greater occurrence.
\end{abstract}

Keywords: Chagas disease control. Entomological surveillance. Synanthropic triatomines. Federal District. Brazil.

\section{RESUMO}

Introdução: As espécies de triatomíneos registradas pela vigilância entomológica da doença de Chagas no Distrito Federal (DF), Brasil, são Panstrongylus megistus, Panstrongylus geniculatus, Panstrongylus diasi, Rhodnius neglectus, Triatoma pseudomaculata e Triatoma sordida. Nosso objetivo foi analisar a ocorrência espacial e temporal das espécies de triatomíneos coletadas no DF, assim como seus índices de infecção natural por tripanosomatídeos. Métodos: Os triatomíneos foram registrados pela Secretaria de Saúde do DF, entre 2002 e 2010, em 20 regiões administrativas. Esta análise retrospectiva considerou o número de adultos e ninfas coletados e infectados de cada espécie no intra e peridomicílio. Resultados: Ao todo, foram coletados 754 triatomíneos em 252 unidades domiciliares notificadas. Panstrongylus megistus foi a espécie mais frequente (65\%), seguida de T. pseudomaculata (14\%). Dos 309 triatomíneos examinados, somente 3 (1\%) espécimes de P. megistus estavam infectados por flagelados morfologicamente similares a Trypanosoma cruzi. A ocorrência espacial mostrou que houve maior diversidade de triatomíneos e maior frequência de T. sordida em áreas rurais. Além disso, houve predominância de $P$. megistus nas áreas urbanas. O número de registros de P. megistus no período chuvoso foi duas vezes maior que no período seco, sendo o maior número de coletas observado no mês de novembro. Conclusões: A presença de espécimes de P. megistus infectados por tripanosomatídeos em domicílios evidencia o potencial risco de infecção humana no DF. Dessa forma, é fundamental que continue a vigilância entomológica, intensificando-a no período chuvoso e nas regiões onde há maior ocorrência.

Palavras-chaves: Controle da doença de Chagas. Vigilância entomológica. Triatomíneos sinatrópicos. Distrito Federal. Brasil.

1. Pós-graduação em Medicina Tropical, Núcleo de Medicina Tropical, Universidade de Brasília, Brasília, DF. 2. Laboratório de Parasitologia Médica e Biologia de Vetores, Faculdade de Medicina, Universidade de Brasília, Brasília, DF. 3. Diretoria de Vigilância Ambiental do Distrito Federal, Secretaria Estadual de Saúde, Brasília, DF.

Address to: Prof. Rodrigo Gurgel Gonçalves. Lab. Parasitologia Médica e Biologia de Vetores/FM/UnB. Caixa Postal 4569, Campus Universitário Darcy Ribeiro, Asa Norte, 70904-970 Brasília, DF, Brasil. Phone: $55613107-1786$

e-mail: rgurgel@unb.br

Received in 28/05/2011

Accepted in 05/08/2011

\section{INTRODUCTION}

Entomological surveillance of Chagas disease in the Federal District of Brazil (DF), began in the 1980s with the establishment of triatomines information posts (PITs). These insects were sent to laboratory tests and were controlled with insecticides ${ }^{1}$. During this period the recorded species were Panstrongylus megistus (Burmeister, 1835), P. geniculatus (Latreille, 1811), P. diasi Pinto \& Lent, 1946, Rhodnius neglectus Lent, 1954, Triatoma pseudomaculata Corrêa \& Espínola, 1964, and T. sordida (Stål, 1859). In 1999, after the decentralization of health actions at The National Health Foundation (FUNASA), activities involving the research, control, and surveillance of triatomines began to be conducted by the Environmental Surveillance Directory (DIVAL) of the Health State Secretariat of Federal District (SES-DF). The surveillance maintains a community participation strategy with a network of 64 PITs in schools and health care units in the administrative regions of DF.

According to Knox and Oliveira ${ }^{2}$, P. megistus is the most widely distributed species in DF, followed by T. pseudomaculata, both recorded in intradomiciliary environments, thus drawing attention to a possible vectorial transmission of Trypanosoma cruzi to humans in DF, where autochthonous cases of Chagas disease have not been reported.

Studies on triatomines in wild environments have recorded $R$. neglectus and Psammolestes tertius Lent \& Jurberg, 1965, in Mauritia flexuosa palm trees in $\mathrm{DF}^{3,4}$. Other studies have shown enzootic circulation of T. cruzi and T. rangeli in gallery forests. Indices of natural infection with T. cruzi were 33\% for mammalian reservoir (Didelphis albiventris) and $9 \%$ for R. neglectus ${ }^{5}$, thus showing the need to maintain entomological surveillance and to monitor the invasion and/or colonization of wild triatomines in domestic environments.

Even without records of vectorial transmission of Chagas disease in DF, there is a possible relation between the human reservoir of T. cruzi $(71,736$ Chagas disease patients in DF, according to the latest serological survey) and synanthropic 
triatomines. Furthermore, the invasion and/or colonization of infected triatomines from wild ecotopes may represent the risk of vectorial transmission with the installation of peridomiciliary and domiciliary cycles of T. cruzi $i^{6,7}$. In this context, the objective of this paper is to analyze the spatial and temporal occurrence of triatomine species collected in DF, as well as their indices of natural infection with trypanosomes to direct actions of entomological surveillance of Chagas disease coordinated by SES-DF.

\section{METHODS}

\section{Study area}

The Federal District of Brazil is geographically located between the parallels $15^{\circ} 30^{\prime}$ and $16^{\circ} 03^{\prime}$ south latitude, and between meridians $47^{\circ} 25^{\prime}$ and $48^{\circ} 12^{\prime}$ west longitude, in Central Brazil, one of the highest areas of the region, the Central Plateau. According to 2010 Census results, the population comprises 2,563,963 people in an area of $5,787,784 \mathrm{~km}^{2}$ divided into 30 administrative regions ${ }^{8}$. The area is filled with plateaus over $1,000 \mathrm{~m}$ in altitude. The average annual rainfall is around $1,600 \mathrm{~mm}$, and the average annual temperature ranges between $18^{\circ} \mathrm{C}$ and $20^{\circ} \mathrm{C}$ with two distinct seasons, the dry season from May to September and the rainy season from October to April, the latter season with the highest temperature records ${ }^{9}$.

\section{Triatomine collection and natural infection}

The insects were collected in intradomiciliary and peridomiciliary environments by residents and then taken to the PITs. Each PIT receives a kit with materials for insect storage, a notepad to keep notes containing the address and location of collection, and tweezers for the handling of specimens.

After notification, the SES-DF public health agents did active searches in these houses and their annexes. The materials used for triatomine collection were metal tweezers and flashlights to inspect cracks and sites deprived of light; when necessary, dislodging liquid (Pirisa 2\%) was applied. The insects were placed in polyethylene vials with shredded paper to better preserve them. The vials were properly numbered, tagged, and recorded on special forms of the Program for Chagas disease Control (PCDCh, SES-DF).

After collection, the insects were sent to the regional laboratory located at DIVAL for taxonomic identification ${ }^{10}$ and for a search of natural infection by flagellates morphologically similar to T. cruzi. The parasitological search was carried out from abdominal compression and subsequent fecal examination of fresh sample, and from slides stained with Giemsa ${ }^{\circledR}$, based on the manual of regulations on organization and operation of laboratories for diagnosis of Chagas disease ${ }^{11}$. The visited domiciles were sprayed with insecticides by public health agents and were georeferenced by location with the support of geographical coordinates obtained with the Global Positioning System (GPS).

The analysis was based on occurrence data of triatomines between 2002 and 2010 in 20 administrative regions of DF, as supplied by PCDCh-SES-DF. For each recorded species, the total number of adults and nymphs collected and infected with flagellates morphologically similar to T. cruzi in intradomicile and peridomicile was analyzed. For statistical analysis, the number of triatomines collected from each identified species was related to the location of collection (administrative regions of DF) and to the month of collection by applying Friedman's nonparametric test (alpha $=0.01)$. The tests were computed with Statistica ${ }^{\circledR}$.

\section{RESULTS}

According to the reports provided by $\mathrm{PCDCh}, 754$ triatomines were collected in 252 domiciles in DF between 2002 and 2010; on average, 84 triatomines were collected and 28 domiciles were reported per year. Eighty-one triatomines were not identified at species level due to poor preservation of specimens. Panstrongylus megistus was the most collected species (65\%), followed by T. pseudomaculata (14\%), T. sordida (8\%), P. geniculatus (7\%), R. neglectus (5\%), and P. diasi (1\%). In this same report, 117 triatomines did not present records from the environment of sampling and/or stages of development, and are not presented in Table 1.

Overall, $46 \%$ of triatomines were collected in intradomicile, these being adult insects more frequent in this environment $(66 \%)$. In peridomicile there was a higher recorded frequency of nymphs (Table 1). In the group of 135 houses with a record of intradomiciliary infestation $16 \%$ presented triatomine colonization and 86 nymphs were collected, especially from P. megistus (66\%). Colonies with up to 33 nymphs of $P$. megistus were also found in peridomicile. Among adults, the number of females was higher than that of males in both environments.

Out of 309 triatomines examined, only 3 (1\%) specimens of P. megistus were infected with flagellates morphologically similar to T. cruzi in domiciles from three administrative regions of DF (Sobradinho, Taguatinga, and Águas Claras).

A relation was observed between the number of triatomines of each species that was collected and the location of occurrence (administrative regions ofDF) (Friedman $=49.9 ; \mathrm{p}<0.01)$; the largest number of collections was observed in Planaltina, a predominantly rural region, with the highest diversity of triatomines and frequency of T. sordida (Figure 1). In most of the other administrative regions

TABLE 1 - Number of triatomines (adults and nymphs) collected in households and infected with flagellates morphologically similar to Trypanosoma cruzi in the Federal District, Brazil, from 2002 to 2010.

\begin{tabular}{|c|c|c|c|c|c|c|c|c|}
\hline \multirow[b]{2}{*}{ Species } & \multicolumn{4}{|c|}{ Intradomicile } & \multicolumn{4}{|c|}{ Peridomicile } \\
\hline & Males & Females & Nymphs & Infected & Males & Females & Nymphs & Infected \\
\hline Panstrongylus megistus & 28 & 56 & 57 & 3 & 41 & 61 & 154 & 0 \\
\hline Triatoma pseudomaculata & 14 & 17 & 5 & 0 & 3 & 2 & 7 & 0 \\
\hline Triatoma sordida & 5 & 16 & 15 & 0 & 0 & 2 & 23 & 0 \\
\hline Panstrongylus geniculatus & 10 & 4 & 0 & 0 & 3 & 1 & 0 & 0 \\
\hline Rhodnius neglectus & 8 & 4 & 8 & 0 & 1 & 0 & 5 & 0 \\
\hline Panstrongylus diasi & 1 & 4 & 1 & 0 & 0 & 0 & 0 & 0 \\
\hline Total & 66 & 101 & 86 & 3 & 48 & 66 & 189 & $\mathbf{0}$ \\
\hline
\end{tabular}




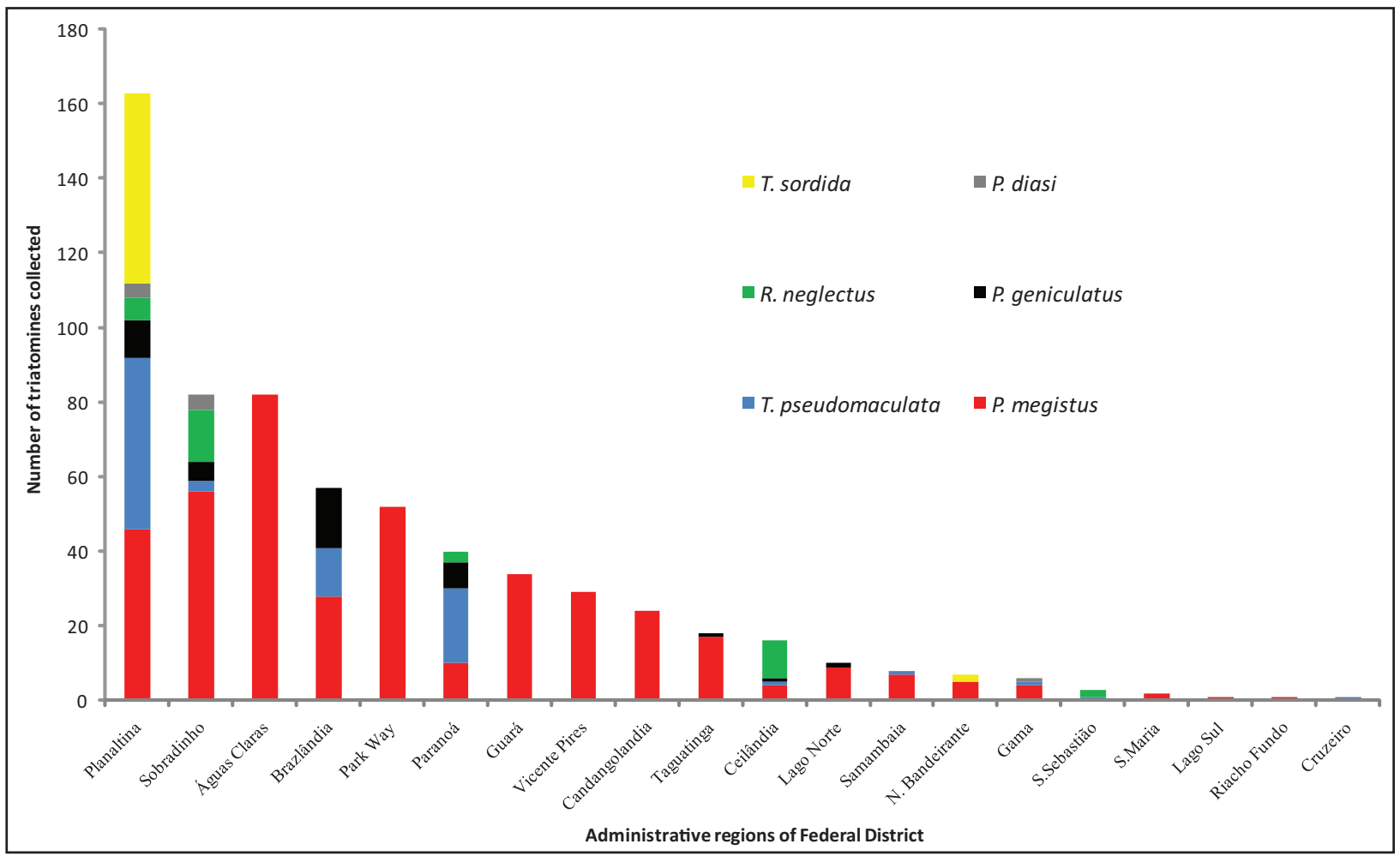

FIGURE 1 - Number of triatomine bugs collected by species in 20 administrative regions of Federal District, Brazil, between 2002 and 2010.

there was predominance of $P$. megistus, this being the only species collected in urban areas like Park Way, Águas Claras, and Guará (Figure 1).

By analyzing monthly data it was possible to observe that the number of triatomine records in the domiciliary environment during the rainy season $(n=155)$ was higher than in the dry season $(n=97)$. Considering only P. megistus (the most collected species in DF), the number of records during the rainy season $(n=77)$ was two times higher than that during the dry season $(n=38)$. The highest number of records occurred in November (Figure 2), which coincides with the onset of the rainy season. No significant differences were found between the number of triatomines collected from the other species over the months $($ Friedman $=11.8 ; \mathrm{p}<0.37)$.

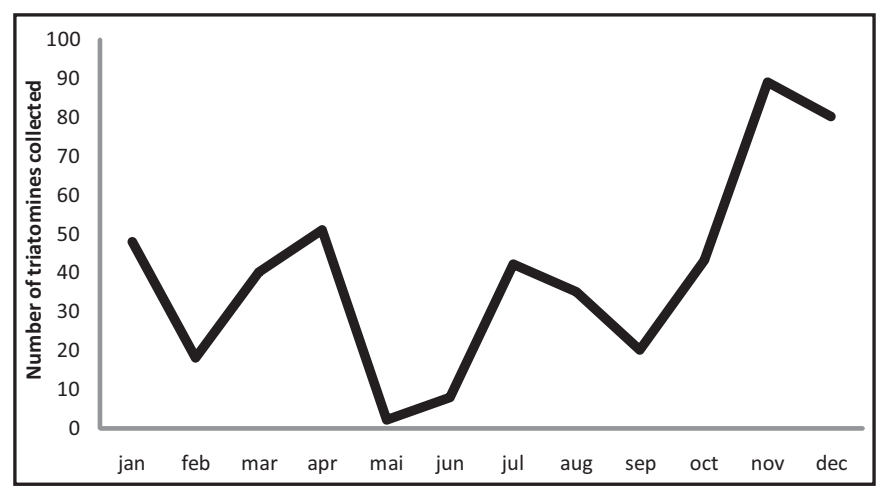

FIGURE 2 - Number of specimens of Panstrongylus megistus collected throughout the year in domiciles of Federal District, Brazil, between January 2002 and December 2010.

\section{DISCUSSION}

The results show that of the six species of triatomines collected in the domiciliary environment, P. megistus is the most important for epidemiological surveillance of Chagas disease in DF. In spite of the low indices for natural infection with trypanosomes for this species in DF, compared with studies in different regions of Brazil ${ }^{12-17}$, it is important to stress that some of the triatomines were found colonizing intradomicile and feeding on human blood according to precipitin tests (unpublished data), thus evidencing the risk of human infection. Our results also show that the spatial occurrence of triatomine species is different in the 20 administrative regions studied in DF, with the highest number of records and species richness observed in Planaltina, a predominantly rural region with the highest frequency of T. sordida. In most of the other administrative regions, areas with intense urbanization, a predominance of $P$. megistus was observed. The data also indicate that during the rainy season there are more records of triatomines, especially of $P$. megistus in November.

Between 1981 and 1996, a total of 4,007 specimens were recorded in DF, and the most collected species were P. megistus, T. pseudomaculata, R. neglectus, and T. sordida ${ }^{1,2}$. Our data show that $P$. megistus remains the most frequent species, followed by T. pseudomaculata, T. sordida, P. geniculatus, R. neglectus, and P. diasi. A study on the geographic distribution of synanthropic triatomines in the state of Goiás in the 1990s indicated the existence of five species: T. sordida, T. infestans, R. neglectus, P. megistus, and T. pseudomaculata ${ }^{14}$. The species with highest natural infection rate with trypanosomes 
was $P$. megistus, as observed in our study in DF. Between 2000 and 2003 four more species were reported in the State of Goiás: P. diasi, T. costalimai, P. geniculatus, and T. lenti ${ }^{18}$. As DF is geographically placed inside the State of Goiás, T. costalimai and T. lenti may also occur in wild environments in DF. Psammolestes tertius is found in some administrative regions of DF, in nests of Phacellodomus ruber birds, which are present in the crowns of $M$. flexuosa palm trees ${ }^{4,19}$. Even though natural and experimental infection of Ps. tertius with T. cruzi $^{20}$ had already been observed, the former species has strong association with wild birds ${ }^{21}$ and, therefore, has low capacity of domiciliation. These behaviors may explain why Ps. tertius was never recorded by entomological surveillance in domiciles of $\mathrm{DF}^{1,2}$. It appears T. infestans never occurred in domiciles of DF as it has not been recorded since the beginning of entomological surveillance ${ }^{1,2}$.

Among the triatomine species found in Brazil, P. megistus presents different degrees of adaptation to the domestic environment. In the south of Brazil it occurs mainly in wild ecotopes ${ }^{16,22}$, unlike in the southeast and northeast regions where P. megistus has greater epidemiological importance for occupying artificial ecotopes ${ }^{15,17,23-25}$. Specimens of $P$. megistus prefer tree hollows in arboreal habitats ${ }^{26,27}$, and they feed on marsupials (Didelphis spp.), which are frequently infected with T. cruzi, thus justifying high infection indices when compared with other species of triatomines ${ }^{26,28,29}$. A study on T. cruzi reservoirs in DF showed that specimens of D. albiventris are responsible for maintaining enzootic circulation of the parasite in the region, where $33 \%$ of these mammals were infected ${ }^{5}$. However, P. megistus has varied feeding habits, also feeding on birds, dogs, cats, rodents, cattle, goats, pigs, and humans s $^{17,27,30}$. Compared with other species such as T. sordida, P. megistus presents higher preferences for human blood, increasing the risk of transmission of T. cruzi by this vector ${ }^{30}$.

In the administrative regions of Park Way, Águas Claras, Sobradinho, Guará, and Taguatinga, areas with high urban densification ${ }^{31}$, P. megistus was the predominant species. Knox et al. ${ }^{32}$ also reported the presence of $P$. megistus in DF in areas with intense anthropic pressure, but with remnants of native vegetation still left in ecological parks and gallery forests close to residences. The development of colonies of $P$. megistus occurs in humid environments ${ }^{23,33}$, and it is possible that gallery forests may be the natural habitat of populations of this species. With the disorganized growth of administrative regions many domiciles are found close to these areas, and this may favor dispersal by flight and domiciliary invasion of these triatomines, stimulated by environmental changes such as reduction of food sources in the wild environment, presence of food sources in peridomicile, and/or rising temperature ${ }^{23,33-38}$. In this context, urban areas surrounded by remainder forests and with marked climate change over the year (as in DF) are likely to favor the invasion of $P$. megistus in artificial ecotopes. Future ecological studies of wild populations of $P$. megistus in gallery forests of DF may clarify these questions. At a later time, genetic analysis and morphological comparisons among wild, domestic, and peridomestic populations may contribute towards an understanding of the infestation dynamics of this species in the domiciliary environment of DF.

Our results indicate that the invasion of $P$. megistus specimens (mainly females) in domiciles of DF occurs more often during the rainy season, especially in November. The increased occurrence of adult specimens of $P$. megistus in the domiciliary environment over the last trimester of the year was observed in other studies in different regions of Brazil ${ }^{30,37,39,40}$, indicating that these triatomines present a higher potential to colonize domiciles and their annexes in the rainy season. In DF, this period is marked by an increase in temperature as from October ${ }^{9}$, which can stimulate the flight activity of P. megistus, as already observed for other species of triatomines ${ }^{38,41}$. The predominance of females in the domiciliary environment indicates their higher invasive potential in relation to males, which may be related to dispersion processes. A study on synanthropic triatomines in the state of Piauí showed that females of T. brasiliensis Neiva, 1911, and T. sordida were more frequently captured than males $^{42}$, as observed for P. megistus and T. sordida in the present study.

Triatoma pseudomaculata was the second most collected species in DF. Unlike P. megistus, it lives under the barks of dead trees and in bird nests ${ }^{27}$, presenting lower indices of natural infection with T. cruzi $^{15}$. This species was often found in domiciles in Planaltina and Paranoá, and in some of these domiciles nymphs were collected, indicating colonization. Even though T. pseudomaculata is more frequent in peridomicile and usually feeds on birds, the colonization in domiciles has been observed in Sobral, Ceará, and Berilo, Minas Gerais, suggesting adaptation of this species in this environment ${ }^{25,43}$. In the northeast of Brazil T. pseudomaculata has great importance for epidemiological surveillance of Chagas disease, its being the most frequent species after T. brasiliensi ${ }^{15,42}$. Some studies have suggested that the increasing presence of T. pseudomaculata in the domiciliary environment is related to climate change, deforestation, and cropland expansion $^{25,44}$, which could explain the higher frequency of this species in the rural areas of Planaltina and Paranoá, observed in the present study.

Regardless of the fact that it has remained the most collected species in cerrado areas of Brazil for the past years ${ }^{18,45-47}$, T. sordida presents a low risk of transmission of T. cruzi to humans because of its peridomiciliary behavior and marked ornithophily ${ }^{15,34,46-47}$. Some studies show that zones of higher occurrence of T. sordida correspond to those of higher and older farm exploration ${ }^{33}$, which may justify the higher frequency of this species in Planaltina.

Rhodnius neglectus is widespread in central Brazil and has an important role in enzootic transmission of T. $\mathrm{cruzi}^{\mathrm{j}, 7}$. Apart from the invasion of adults in domiciles ${ }^{48}$, there is evidence of household infestation of $R$. neglectus (with bugs occasionally establishing breeding colonies) in the States of Minas Gerais, Goiás, and São Paulo ${ }^{18,49,50}$. R. neglectus occurs predominantly in wild environments, inhabiting different species of palm trees in Brazil ${ }^{11-53}$. In DF it can be found in M. flexuosa palm trees ${ }^{3,4,19}$, and sporadic occurrence in the administrative regions of Planaltina, Sobradinho, Ceilândia, and São Sebastião may be associated with the presence of palm trees in peridomicile. The role of these peridomiciliary palm trees in the maintenance of triatomines in DF should be evaluated in future studies.

Panstrongylus geniculatus occurred especially in Brazlândia, in the northwest region of DF, in agreement with the observations of Knox et al. ${ }^{32}$. In the wild environment $P$. geniculatus inhabits, preferentially, armadillo burrows (Dasypus spp. ${ }^{26,27}$, but it has been found in the domiciliary environment in different states of Brazil ${ }^{18,54-55}$.

Punctual distributions of $P$. diasi in DF were also observed. This species is distributed in areas of cerrado in central Brazil ${ }^{18,56}$ and has been found in the domiciliary environment without description of wild ecotopes ${ }^{26}$. 
In comparing occurrence records in peridomicile and intradomicile, T.pseudomaculata, T. sordida, P.geniculatus, R. neglectus, and $P$. diasi occurred more in intradomicile, which cannot be considered a preference for this environment as surveillance occurs when residents notify invasion of these insects in their domiciliary environment, not worrying about insects that may be co-habiting in peridomiciliary environments. Therefore, notifications from PITs are, in general, intradomiciliaries ${ }^{35}$. Peridomiciliary captures occurred mainly after the research of public health agents in households, as observed by Villela et al. ${ }^{17}$. Because secondary data were used, a lot of information, such as sampling location, species, and location (address), was lost due to incorrect completion of forms. Another limitation of this study was the loss of data on natural infection of triatomines. Only $40 \%$ of the collected insects were properly examined, as many died and were dry before examination because of problems with transport and logistics. Moreover, parasitological tests of collected insects could have been more efficient, including molecular diagnosis for detection of T. cruzi.

After about 30 years of vector surveillance of Chagas disease in DF, P. megistus remains the species of highest epidemiological importance. The risk of vectorial transmission of T. cruzi to humans in DF may be considered low due to the good living conditions of most inhabitants of the area and the low natural infection rate of triatomines detected in the present study. However, the presence of $P$. megistus specimens infected with flagellates morphologically similar to T. cruzi in domiciles shows that the risk of human infection still exists in DF. Thus, it is essential to continue entomological surveillance, intensifying it during the rainy season and in administrative regions of greater occurrence, as shown in the present study. Moreover, we recommend the strengthening of the PIT network and community encouragement, based on educational actions, for active participation in entomological surveillance. In this way, the detection of synanthropic triatomines would be more efficient, thus reducing the chances of colonization of these insects in domiciliary units of DF. Other zoonoses transmitted by vectors in DF, such as visceral leishmaniasis ${ }^{57}$, also in the scope of epidemiological surveillance, call to attention investments in basic and applied research involving vector transmission in the region. In this sense, we bear in mind that American trypanosomiasis cannot be eradicated completely, the more likely scenario being a reduction in human infection risk with T. cruzi, especially from strategies of surveillance and vector control.

\section{ACKNOWLEDGMENTS}

We are thankful to the technicians of SES/DIVAL, who participated in triatomine sampling in the administrative regions of DF. We are also grateful to César Augusto Cuba Cuba, and Márcio Vinhaes for reviewing the manuscript.

\section{CONFLICT OF INTEREST}

The authors declare that there is no conflict of interest.

\section{FINANCIAL SUPPORT}

Coordenação de Aperfeiçoamento de Pessoal de Nível Superior and Conselho Nacional de Desenvolvimento Científico e Tecnológico.

\section{REFERENCES}

1. Assis AL. Vigilância epidemiológica da doença de Chagas no Distrito Federal [Post-Graduate Public Health Monograph]. [Brasília (DF)]: Universidade de Brasília; 1999. 23p.

2. Knox MB, Oliveira C. Distribuição de triatomíneos vetores de Doença de Chagas no DF- 1996/2002. In: Fundação Carlos Chagas Filho de Amparo à Pesquisa do Estado do Rio de Janeiro (FAPERJ), editor. Resumos do VII Congresso Brasileiro de Saúde Coletiva. Rio de Janeiro: Associação Brasileira de Pós-Graduação em Saúde Coletiva (Abrasco); 2003. p.884

3. Gurgel-Gonçalves R, Palma ART, Menezes MNA, Leite RN, Cuba CAC. Sampling Rhodnius neglectus (Triatominae) in Mauritia flexuosa palm trees (Arecaceae): a field study in the Brazilian Savanna. Med Vet Entomol 2003; 17:347-349.

4. Gurgel-Gonçalves R, Duarte MA, Ramalho ED, Romaña CA, Cuba CAC. Distribuição espacial de populações de Triatominae (Hemiptera, Reduviidae) em palmeiras da espécie Mauritia flexuosa no Distrito Federal, Brasil. Rev Soc Bras Med Trop 2004; 37:241-247.

5. Gurgel-Gonçalves R, Ramalho RED, Duarte MA, Palma ART, Abad-Franch F, Carranza JC, et al. Enzootic transmission of Trypanosoma cruzi and T. rangeli in the Federal District of Brazil. Rev Inst Med Trop São Paulo 2004; 46:323-330.

6. Silveira AC, Vinhaes M. Doença de Chagas: aspectos epidemiológicos e de controle. Rev Soc Bras Med Trop 1998; 31(supl 2):15-60.

7. Gurgel-Gonçalves R, Cuba-Cuba CA. Transmissão enzoótica de Trypanosoma cruzi no Distrito Federal: fator de risco para a Doença de Chagas? Rev Universa Ciên Biol Saude Med 2007; 2:26-28.

8. Instituto Brasileiro de Geografia e Estatística (IBGE). Estimativas da população para 2010 [Internet]. IBGE; [updated 2010 jan 1, cited $2010 \mathrm{feb} 20$ ]. Available from: http://www.ibge.gov.br/estadosat/perfil.php?sigla=df/.

9. Silva Júnior MC, Felfili JM, Nogueira PE, Rezende AV. Análise florística das Matas de Galeria no Distrito Federal. In: Ribeiro JF, editor. Cerrado: Matas de Galeria. Brasília, Embrapa; 1998. p. 53-84.

10. Lent H, Wygodzinsky P. Revision of the Triatominae (Hemiptera, Reduviidae) and their significance as vectors of Chagas Disease. Bull Am Mus Nat Hist $1979 ; 163: 125-529$.

11. Superintendência de Campanhas de Saúde Pública. Manual de normas sobre organização e funcionamento de laboratórios de diagnóstico da doença de Chagas. Brasília: Ministério da Saúde; 1981.

12. Fernandes AJ, Chiari E, Casanova C, Dias JCP, Romanha AJ. The threat of reintroduction of natural transmission of Chagas' disease in Bambuí, Minas Gerais state, Brazil, due to Panstrongylus megistus. Mem Inst Oswaldo Cruz 1992; 87:285-289.

13. Steindel M, Toma HK, Pinto CJC, Grisard EC, Schlemper JBR. Colonização de Ecótopos artificiais pelo Panstrongylus megistus na Ilha de Santa Catarina, Florianópolis Santa Catarina, Brasil. Rev Inst Med Trop São Paulo 1994; $36: 43-50$.

14. Silva IG, Silva JL, Camargo MF, Elias CN, Santos AH, Silva HHG, et al. Infestação de vetores da tripanossomíase americana no ambiente domiciliar no Estado de Goiás. Rev Patol Trop 1995; 24:41-47.

15. Dias JCP, Machado EMM, Fernandes AL, Vinhaes MC. Esboço geral e perspectivas da doença de Chagas no Nordeste do Brasil. Cad Saúde Publica 2000; 16:S13-S34.

16. Bedin C, Mello F, Wilhelms TS, Torres MA, Estima C, Ferreira CF, et al. Vigilância ambiental: Doença de Chagas no Rio grande do Sul. Bol Epidemiol 2009; 11:1-8.

17. Villela MM, Souza JMB, Melo VP, Dias JCP. Avaliação do Programa de Controle da Doença de Chagas em relação à presença de Panstrongylus megistus na região centro-oeste do Estado de Minas Gerais, Brasil. Cad Saude Publica 2009; 25:907-917.

18. Oliveira AW, Silva IG. Distribuição geográfica e indicadores entomológicos de triatomíneos sinantrópicos capturados no Estado de Goiás. Rev Soc Bras Med Trop 2007; 40:204-208.

19. Gurgel-Gonçalves R, Cuba-Cuba CA. Estrutura de populações de Rhodnius neglectus (Lent) e Psammolestes tertius (Lent \& Jurberg) (Hemiptera, Reduviidae) em ninhos de pássaros (Furnariidae) presentes na palmeira Mauritia flexuosa no Distrito Federal, Brasil. Rev Bras Zool 2007; 24:157-163. 
20. Barretto MP. Epidemiologia. In: Brener Z, Andrade AA, editors. Trypanosoma cruzi e Doença de Chagas. Rio de Janeiro: Guanabara Koogan; 1979. p. 89-291.

21. Gurgel-Gonçalves R, Cuba CAC. Infestation of thornbird nests (Passeriformes: Furnariidae) by Psammolestes tertius (Hemiptera: Reduviidae) across Brazilian Cerrado and Caatinga ecoregions. Zoologia 2011; 28: 411-414.

22. Ramos CJR, Tavares KCS, Komati LKO, Miletti LC. Colonização intradomiciliar de Panstrongylus megistus (Hemiptera, Reduviidae, Triatominae) em São José do Cerrito, SC: primeiro relato. Rev Soc Bras Med Trop 2008; 41:421-423.

23. Forattini OP. Biogeografia, origem e distribuição da domiciliação de triatomíneos no Brasil. Rev Saude Publica 1980; 14:265-299.

24. Nascimento C, Marassá AM, Curado I, Piazza RMF. Encontro de Panstrongylus megistus em ecótopo artificial: domiciliação ou mera visitação? Rev Soc Bras Med Trop 1997; 30:333-336.

25. Assis GFM, Azeredo BVM, Gorla D, Diotaiuti L, Lana M. Entomological surveillance of Chagas disease in Berilo municipality, Jequitinhonha Valley, State of Minas Gerais, Brazil. Rev Soc Bras Med Trop 2009; 42:615-621.

26. Patterson JS, Barbosa SE, Feliciangeli MD. On the genus Panstrongylus Berg 1879: evolution, ecology and epidemiological significance. Acta Trop 2009; 110:187-199.

27. Carcavallo RU, Rodríguez MEF, Salvatella R, Curto-de-Casas SI, Sherlock I, Galvão C, et al. Habitats and related fauna. In: Carcavallo RU, Galíndez Girón I, Jurberg J, Lent H, editors. Atlas of Chagas Disease Vectors in Americas. Vol II. Rio de Janeiro: Editora Fiocruz; 1998. p. 561-600.

28. Rocha-e-Silva EO, Andrade JCR, Rodrigues VLCC. Investigação de foco, uma das atividades das campanhas de controle dos transmissores da tripanossomíase americana. Rev Saude Publica 1978; 12:425-431.

29. Forattini OP, Ferreira AO, Silva EOR, Rabello EX. Aspectos ecológicos da Tripanossomíase americana: VIII - Domiciliação de Panstrongylus megistus e sua presença extradomiciliar. Rev Saude Publica 1977; 11:73-86.

30. Forattini OP, Barata JMS, Santos JLF, Silveira AC. Hábitos alimentares, infecção natural e distribuição de triatomíneos domiciliados na região central do Brasil. Rev Saude Publica 1982; 16:171-204.

31. United Nations Educational, Scientific and Cultural Organization. Vegetação no Distrito Federal - Tempo e espaço. Brasília: UNESCO; 2000.

32. Knox MB, Oliveira C, Buffon S. Mapeamento de triatomíneos no Distrito Federal utilizando o geoprocessamento. Rev Soc Bras Med Trop 2008; 41 (supl 1):37.

33. Forattini OP, Santos JLF, Ferreira OA, Rocha-e-Silva EO, Rabello EX. Aspectos ecológicos da tripanossomíase americana: XVI - dispersão e ciclos anuais de colônias de Triatoma sordida e de Panstrongylus megistus espontaneamente desenvolvidas em ecótopos artificiais. Rev Saude Publica 1979; 13:299-313.

34. Forattini OP, Ferreira OA, Silva EOR, Rabello EX. Aspectos ecológicos da tripanossomíase americana: XV - desenvolvimento, variação e permanência de Triatoma sordida, Panstrongylus megistus e Rhodnius neglectus em ecótopos artificiais. Rev Saude Publica 1979; 13:220-234

35. Pickenhayn J, Guimaraes RB, Lima SC, Curto S. Processo de urbanização da doença de chagas na Argentina e no Brasil. Rev Bras Geo Med Saude 2008; 4:58-69.

36. Carvalho ME, Silva RA, Barata JMS, Domingos MF, Ciaravolo RMC, Zacharias F. Soroepidemiologia da Tripanosomíase Americana na região do Litoral Sul, São Paulo. Rev Saude Publica 2003; 37:49-58.

37. Forattini OP, Ferreira AO, Rabello EX, Barata JMS, Santos JLF. Aspectos ecológicos da tripanossomíase americana: XX - Desenvolvimento e ciclos anuais de colônias de Panstrongylus megistus em ecótopos artificiais, no ambiente peri e extradomiciliar. Rev Saude Publica 1984; 18:30-40.

38. Lehane MJ, McEwen PK, Whitaker CJ, Schofield CJ. The role of temperature and nutritional status in flight initiation by Triatoma infestans. Acta Trop 1992; 52:27-38.

39. Dias E, Dias JCP. Variações mensais da incidência das formas evolutivas do Triatoma infestans e do Panstrongylus megistus no município de Bambuí, Estado de Minas Gerais: (II nota: 1951 a 1964). Mem Inst Oswaldo Cruz 1968; 66:209-226.

40. Mendes PC, Lima SC, Paula, MBC, Souza AA, Rodrigues EAS, Limongi JE. Doença de chagas e a distribuição espacial de triatomíneos capturados em Uberlândia, Minas Gerais - Brasil. Rev Bras Geo Med Saude 2008; 3:176-204.
41. Gorla DE, Catalá SS, Grillo MP. Efecto de la temperatura sobre la distribución de Triatoma infestans y el riesgo de transmisión vectorial de la enfermedad de Chagas en Argentina. Acta Toxicol Argent 1997; 5:36-39.

42. Gurgel-Gonçalves R, Pereira FCA, Lima IP, Cavalcante RR. Distribuição geográfica, infestação domiciliar e infecção natural de triatomíneos (Hemiptera: Reduviidae) no Estado do Piauí, Brasil, 2008. Rev Pan-Amaz Saude 2010; 1: 57-64.

43. Freitas SPC, Lorosa ES, Rodrigues DCS, Freitas ALC, Gonçalves TCM. Fontes alimentares de Triatoma pseudomaculata no Estado do Ceará, Brasil. Rev Saude Publica 2005; 39:27-32.

44. Assis GFM, Azeredo BVM, Carbajal-de-la-Fuente AL, Diotaiuti L, Lana M. Domestication of Triatoma pseudomaculata (Côrrea \& Espínola 1964) in the Jequitinhonha Valley of the State of Minas Gerais. Rev Soc Bras Med Trop 2007; 40:391-396.

45. Diotaiuti L, Loiola CF, Falcão PL, Dias JCP. The ecology of Triatoma sordida in natural environments in two different regions of the state of Minas Gerais, Brazil. Rev Inst Med Trop São Paulo 1993; 35:237-245.

46. Diotaiuti L, Azeredo BVM, Busek SCU, Fernandes AJ. Controle do Triatoma sordida no peridomicilio rural do municipio de Porteirinha, Minas Gerais, Brasil. Pan Am J Public Health 1998; 3:21-25.

47. Pires HHR, Borges EC, Andrade RE, Lorosa ES, Diotaiuti L. Peridomiciliary infestation with Triatoma sordida Stal, 1859 in the county of Serra do Ramalho, Bahia, Brasil. Mem Inst Oswaldo Cruz 1999; 94:147-149.

48. Gurgel-Gonçalves R, Abad-Franch F, Ferreira JB, Santana D, Cuba CAC. Is Rhodnius prolixus (Triatominae) invading houses in central Brazil? Acta Trop 2008; 90-98.

49. Barretto MP, Siqueira AF, Ferriolli FF, Carvalheiro JR. Estudos sobre reservatórios e vetores do Trypanosoma cruzi.XXIII. Observações sobre criadouros do Rhodnius neglectus Lent, 1954 em biótopos artificiais (Hemiptera, Reduviidae). Rev Inst Med Trop São Paulo 1968; 10:163-170.

50. Silva RA, Bonifácio PR, Wanderley DMV. Doença de Chagas no estado de São Paulo: comparação entre pesquisa ativa de triatomíneos em domicílios e notificação de sua presença pela população em área sob vigilância entomológica. Rev Soc Bras Med Trop 1999; 32:653-659.

51. Diotaiuti L, Dias JC. Occurrence and biology of Rhodnius neglectus Lent, 1954 in palm trees of suburban areas of Belo Horizonte, Minas Gerais. Mem Inst Oswaldo Cruz 1984; 79:293-301.

52. Gurgel-Gonçalves R, Cuba CAC. Predicting the potential geographical distribution of Rhodnius neglectus (Hemiptera, Reduviidae) based on ecological niche modeling. J Med Entomol 2009; 46:952-960.

53. Abad-Franch F, Monteiro FA, Jaramillo NO, Gurgel-Gonçalves R, Dias FBS, Diotaiuti L. Ecology, evolution and the long-term surveillance of vector-borne Chagas disease: A multi-scale appraisal of the tribe Rhodniini (Triatominae). Acta Trop 2009; 112:159-177.

54. Valente VC. Potential for domestication of Panstrongylus geniculatus (Latreille, 1811) (Hemiptera: Reduviidae: Triatominae) in the municipality of Muaná, Marajó Island, Pará State, Brazil. Rev Soc Bras Med Trop 1999; 32:595-597.

55. Leite GR, Santos CB, Falqueto A. Insecta, Hemiptera, Reduviidae, Panstrongylus geniculatus: Geographic distribution map. Check List 2007; 3:147-152.

56. Carcavallo RU, Curto-de-Casas SI, Sherlock I, Galíndez-Girón I, Jurberg J, Galvão C, et al. Geographical distribution and alti-latitudinal dispersion. In: Carcavallo RU, Galíndez Girón I, Jurberg J, Lent H, editors. Atlas of Chagas disease vectors in Americas. Vol. III. FIOCRUZ: Rio de Janeiro; 1999. p. 747-792.

57. Carranza-Tamayo CO, Carvalho MSL, Bredt A, Bofil MIR, Rodrigues RMB, Silva $\mathrm{AD}$, et al. Autochthonous visceral leishmaniasis in Brasília, Federal District, Brazil. Rev Soc Bras Med Trop 2010; 43:396-399. 